\title{
Life cycle of the marbled octopus, Amphioctopus aegina (Gray) (Cephalopoda: Octopodidae) reared in the laboratory
}

\author{
PICHITRA PROMBOON ${ }^{1}$, JARUWAT NABHITABHATA ${ }^{2}$ \\ and TEERAPONG DUENGDEE ${ }^{1}$
}

\footnotetext{
${ }^{1}$ Department of Marine Science, Faculty of Fisheries, Kasetsart University, Chatuchak, Bangkok 10900, Thailand. ${ }^{2}$ Centre for Biodiversity of Peninsular Thailand, Faculty of Science, Prince of Songkla University, Hatyai, Songkhla 90112, Thailand.E-mail: jaruwat.n5@gmail.com, jaruwat.n@psu.ac.th
}

SUMMARY: Reproducing small eggs and planktonic hatchlings is a reproductive strategy of many species of benthic octopods although it is considered a pleisiomorphic state. The young in the planktonic and settling phases have a high energy consumption and require live food of specific size range characteristics, causing difficulties in obtaining appropriate food organisms for rearing experiments through the entire life cycle. This study obtained information on details of life cycle characteristics of Amphioctopus aegina (Gray) by resolving these difficulties. The aspects of life cycle of A. aegina were similar to those of other benthic octopus with a similar reproductive strategy. Growth was allometric, consisting of 3 phases in terms of body weight, including a transitional phase for the early settling stage. Feeding and conversion efficiency peaked over a 2-month period prior to reproduction, representing the period of energy storage. Growth from hatching to spawning took approximately $74 \%$ of the entire life span and the reproductive phase itself took $34 \%$. Such longevities are similar to those of other benthic cephalopods with planktonic hatchlings. Overall similarities in these cephalopod taxa attest to the fitness of a life-history strategy involving production of planktonic offspring from benthic adults. A. aegina is the second benthic octopus species with planktonic hatchlings for which the life cycle has been completed through rearing in the laboratory.

Keywords: octopus, Amphioctopus aegina, Cephalopoda, life cycle, reared.

RESUMEN: Ciclo vital del pulpo marmóreo, Amphioctopus aegina (Gray) (Cephalopoda: Octopodidae) CRiado EN LABORATORIO. - El desove de pequeños huevos que darán origen a plancton constituye la estrategia de reproducción de numerosos octópodos bénticos, aunque se asocia a un estado plesiomórfico. Las nuevas criaturas en fase planctónica y de asentamiento requieren un gran consumo energético y nutrientes vivos con características y dimensiones específicas, lo que dificulta la obtención de organismos que les sirvan de alimento a lo largo de todo el ciclo vital. A partir de este estudio se han obtenido datos sobre las características del ciclo vital del Amphioctopus aegina (Gray) mediante la resolución de estas dificultades. Muchos aspectos del ciclo vital del A. aegina resultaron muy similares a los de otros pulpos bénticos con una estrategia de reproducción parecida. Se produjo un crecimiento alométrico en tres fases, según el peso corporal, que incluía una fase de transición en el periodo de asentamiento inicial. La eficacia en la alimentación y la conversión alcanzó su punto máximo en los 2 meses previos a la reproducción, que representan un periodo de almacenamiento energético. El crecimiento desde la eclosión hasta el desove fue aproximadamente el $74 \%$ del ciclo vital completo, y la fase reproductiva en sí supuso un 34\%. Tal longevidad es compartida por otros cefalópodos bénticos con desoves planctónicos. Las similitudes generales entre estas categorías taxonómicas de cefalópodos confirman el éxito de esta estrategia de ciclos vitales en la producción de crías planctónicas por parte de adultos bénticos. A. aegina es la segunda especie de pulpo béntico con desove planctónico cuyo ciclo vital ha logrado completarse mediante la cría en laboratorio.

Palabras clave: pulpo, Amphioctopus aegina, Cephalopoda, ciclo vital, criado. 


\section{INTRODUCTION}

One major aspect of the evolutionary adaptations of benthic octopods is exhibited in 2 life-history strategies. The first one is production of relatively few large eggs resulting in larger hatchlings with a benthic mode of life. The second one is production of numerous small eggs resulting in hatchlings with a planktonic mode of life. Boletzky (1974, 1977, 1978-1979) proposed that when egg length is more than $10 \%$ of mantle length of adults, the resulting hatchlings are benthic (with relative mantle length of 6-20\%) while egg lengths of less than $10 \%$ of adult mantle length are associated with planktonic hatchlings (with a mantle length of 2-5\%). Producing large eggs, and hence benthic hatchlings, is considered an apomorphic state and producing small eggs and planktonic young is a pleisiomorphic state (Boletzky, 1977). The disadvantages of the planktonic mode of life for young octopods are higher energetic cost and higher risk of predation compared with the benthic mode. However, in the context of the evolutionary trade-offs, the advantage of the planktonic mode is that the planktonic hatchlings possess considerable potential for dispersal, assuring the distribution of the species (Villanueva and Norman, 2008). The planktonic life stage of the young octopods also enables them to occupy different niches and potentially to locate alternative food sources, allowing higher rates of energy consumption. These abilities could explain why a pleisiomorphic state such as the planktonic mode of life is still maintained through natural selection in species with wider distribution.

Knowledge of the life cycle of benthic octopus species with planktonic hatchlings is still limited. The available information is mostly from species with benthic hatchlings, e.g. Octopus bimaculoides Pickford and McConnaughhey (Forsythe and Hanlon, 1988), $O$. briareus Robson (Hanlon and Wolterding, 1989), $\mathrm{Pa}$ roctopus digueti Perrier and Rochebrune (as $O$. digueti) (DeRusha et al., 1987), O. joubini Robson (Thomas and Opresko, 1973; Forsythe and Hanlon, 1980, Forsythe, 1984), O. maya Voss and Solis (Van Heukelem, 1977), and Hapalochlaena maculosa (Hoyle)(Tranter and $\mathrm{Au}-$ gustine, 1973). The information available to date for octopus with planktonic hatchlings comes from studies of just 2 species Octopus vulgaris Cuvier and Enteroctopus dofleini (Wulker), which are relatively well known due to their economic importance (Villanueva and Norman, 2008).

Information on life cycle characteristics, including feeding, growth and behaviour, can be obtained through captive rearing. The life histories of cephalopods are highly variable, deriving from the plasticity of their growth as affected by various biotic and abiotic factors. Forsythe and Van Heukelem (1987) observed that information on cephalopod growth can be derived from both laboratory rearing and field surveys. The major disadvantage of captive rearing is that it is unnatural or artificial. However, the advantage of rearing is that growth and life cycles can be measured and monitored under known conditions; environmental factors can be controlled or monitored and the impact of predation, density and food abundance is removed or controlled. Indeed, most of the available information on octopod growth over their life cycles comes from laboratory rearing (Hanlon, 1987) and, as mentioned above, concerns species with benthic hatchlings. At present, 24 species of octopods with planktonic hatchlings have been reared but hatchlings of only 2 species have been reported to develop to the settling stage: $E$. dofleini and O. vulgaris (Nabhitabhata, 1985, 1995; Nabhitabhata et al., 2003; Villanueva and Norman, 2008). Only $O$. vulgaris has been reared through its complete life cycle in captivity (Iglesias et al., 2004). Other benthic cephalopods with planktonic hatchlings and benthic adults, Sepiella inermis Ferrussac and d'Orbigny (Nabhitabhata, 1997) and Euprymna hyllebergi Nateewathana (Nabhitabhata et al., 2005), could also be reared through their complete life cycles. Finding whether those taxa have common characters of life cycles is informative, inferring the evolutionary fitness of this life-history strategy.

Amphioctopus aegina (Gray) is a moderate-sized benthic octopus with a mantle length $40-100 \mathrm{~mm}$. Fresh specimens can be recognized by the coloured longitudinal stripe on their dorsum (Fig. 1) with a cream transverse bar on the dorsal head between the eyes (Nateewathana, 1997; Norman, 1998, 2000). The colour of the dorsal stripe varies among localities and Norman (2000) has suggested that A. aegina is a species complex. Distribution is wide in the coastal zone of the Indian and Western Pacific Ocean, from $30^{\circ}$ to $140^{\circ} \mathrm{E}$ and $40^{\circ} \mathrm{N}$ down to $20^{\circ} \mathrm{S}$ (Roper et al., 1984). In Thai waters, this species is common, living in muddy areas (Nateewathana, 1997).

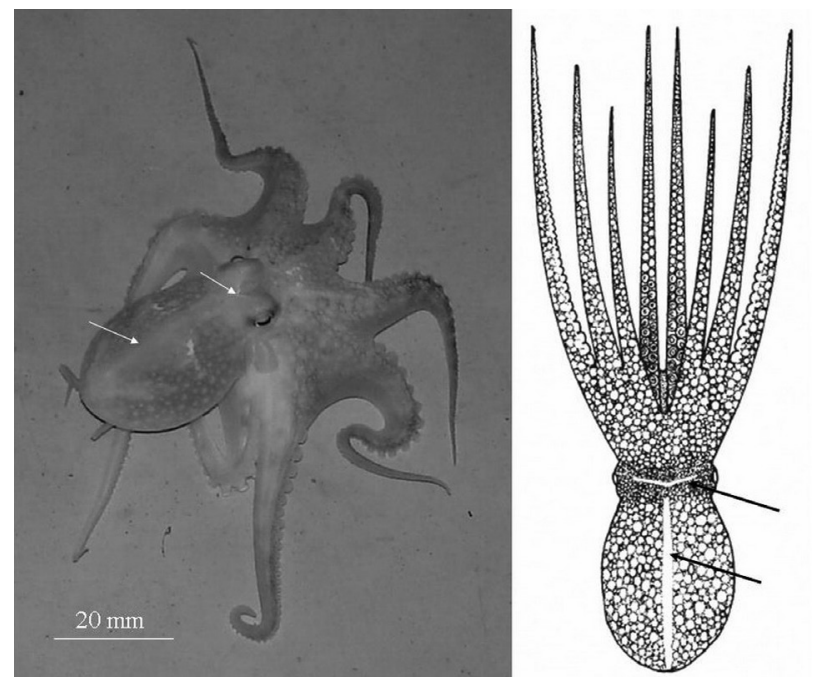

FIG. 1. - Marbled octopus, Amphioctopus aegina (Gray, 1849). Arrows indicate the cream transverse bar on the head (above) and the longitudinal cream stripe on the mantle (below). Drawing source: Norman (1998). 


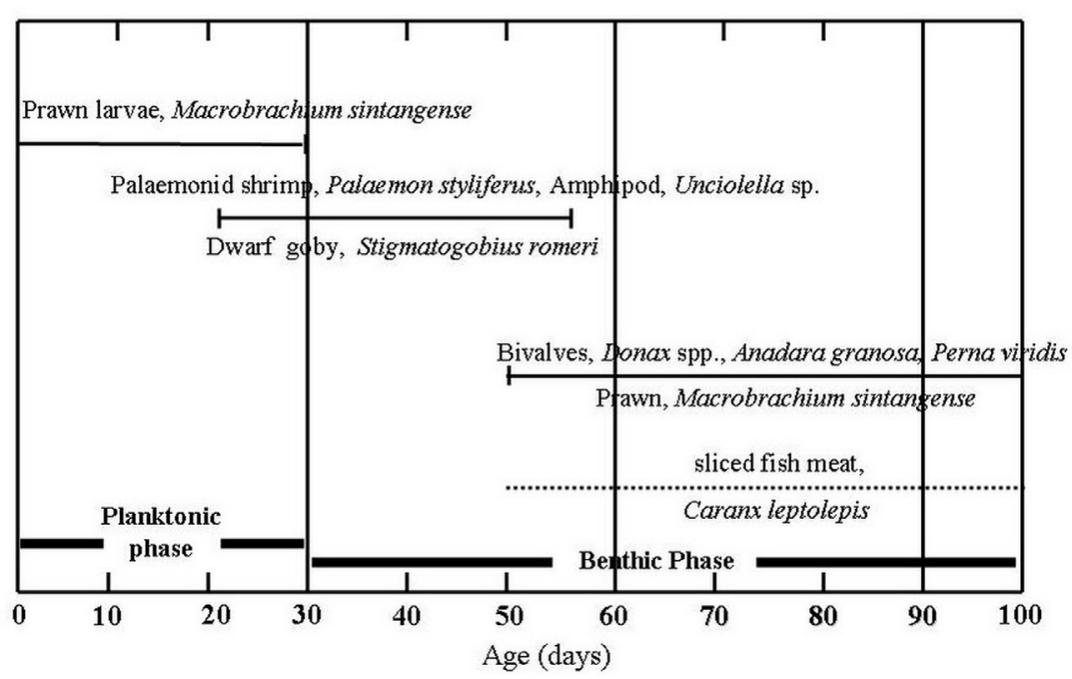

FIG. 2. - Diagram of feeding of Amphioctopus aegina on various live (full line) and non-live (dashed line) food corresponding to the age (d) after hatching.

Phanichpong (1985) described the reproductive biology and behaviour of A. aegina (as $O$. dollfusi) and suggested that this species reproduced all year round in Thailand, with the highest peak from March to May (summer to the early rainy season). The ovary weight of mature females was normally $5-7 \%$ of the body weight, reaching a maximum of $17 \%$ during the peak of reproduction. The testis weight of mature males was approximately $3-4 \%$ of body weight (with a maximum of 9.4\%) throughout the year (Phanichpong, 1985). Mating, following the "enveloping pattern" (Gabe, 1975; Hartwick, 1983), was also observed in the laboratory. Other aspects of the life cycle of A. aegina remain little known, though it is an economically important species in Thailand. About $15000 \mathrm{t}$ of octopus are fished annually from Thai waters, about $12 \%$ of the total cephalopod catch. This includes A. aegina (Supongpan, 1995), which is treated under the name Octopus dollfusi Robson, its junior synonym (Nateewathana, 1997; Norman and Hochberg, 2005a).

The outstanding problem for laboratory rearing of octopods is that the planktonic young octopods require live food of a specific size range and characteristics (Hanlon, 1987; Boyle and Rodhouse, 2005). The subsequent transitional settlement period also involves a transition to utilizing a new type and size of food organisms. The present study aims to resolve these difficulties for $A$ aegina, making it only the second benthic octopus species with planktonic hatchlings (and the first such species of moderate size) for which the life cycle has been completed, and to determine details of morphology, feeding, growth and behaviour of $A$. aegina throughout its life cycle, including its embryonic phase and post-hatching to adult development stages.

Information on the life cycle and growth of $A$. aegina is potentially valuable to underpin sustainable fishing of the species and to provide a better under- standing of, and more detailed insight into, how egg size and juvenile habitat in octopods relate to other life cycle features, compared with other benthic cephalopods with which their niches overlap, i.e. those octopus species with a similar reproductive strategy and also other benthic cephalopods with planktonic offspring. In addition, determination of the morphological characters of the early life stages of this species will help to clarify previous taxonomic identifications based on wild planktonic young without a direct link to the spawning adults.

\section{MATERIALS AND METHODS}

\section{Maintenance and rearing of live specimens}

Broodstock of A. aegina was collected live from octopus traps operating along the coast of Rayong Province in the eastern part of the Gulf of Thailand, South China Sea, Pacific Ocean. Twelve females with an average dorsal mantle length (ML) of $60.5 \pm 4.28 \mathrm{~mm}$ and a weight of $78.39 \pm 9.65 \mathrm{~g}$ and 10 males of $57.00 \pm 4.54 \mathrm{~mm}$ and $49.00 \pm 10.19 \mathrm{~g}$ were maintained on-board and then transported to the cephalopod hatchery of the Rayong Coastal Fisheries Research and Development Centre. The octopus were separated by sex and reared for $7 \mathrm{~d}$ in 1800-mm-diameter circular concrete tanks with a capacity of $2 \mathrm{~m}^{3}$ and $300 \mathrm{~mm}$ water depth. Pieces of PVC pipe (50 $\mathrm{mm}$ diameter, $150 \mathrm{~mm}$ length) were supplied as shelters in the tanks. The tanks were equipped with aeration devices and supplied with running filtered seawater in order to minimize any temperature change. The octopus were fed twice daily at 08:00 $\mathrm{h}$ and 17:00 h. Tanks were cleaned by siphoning out the water and about 50\% by volume was replaced daily. One pair of octopuses was then reared in each tank under similar conditions. The octopuses mated and spawned in the tanks. After spawning, the male was excluded. 
Hatchlings were reared in 50-L-capacity cylindrical PVC tanks with dark blue tank walls, a water depth of $150 \mathrm{~mm}$ and a stocking density of 1 individual $\cdot \mathrm{L}^{-1}$. The tanks were equipped with air stones attached to half-circular PVC pipes in order to direct the current. Hatchlings were fed ad libitum twice daily with live prawn larvae in a zoeal stage, Macrobrachium sintangense (De Man) (available from commercial hatcheries) of 1-2 mm total length for $30 \mathrm{~d}$ after hatching (Fig. 2). Eighteen batches of the octopus were studied from May 2006 to April 2007.

Live amphipods, Unciolella sp. Chevreux, wild palaemonid shrimps, Palaemon styliferus (H. MilneEdwards) and dwarf gobies, Stigmatogobius romeri (M. Weber), collected from the wild, were fed to the young octopuses at their early settling stage for 20 d (days 30-50). The water depth was gradually increased to $300 \mathrm{~mm}$ at 30 days. Tanks were cleaned by siphoning out the water and about $80 \%$ by volume was replaced daily. The settling young were transferred to 1800 -mm-diameter circular concrete tanks with grey tank walls and maintained at a density of 1 individual. $\mathrm{L}^{-1}$. Water depth was decreased to 150 $\mathrm{mm}$ and coral pebbles were supplied as shelters. After $50 \mathrm{~d}$, the octopuses were trained to feed on dead fish meat, Selaroides leptolepis (Cuvier). Live bivalves, Donax spp. Linnaeus, Anadara granosa (Linnaeus) and Perna viridis (Linnaeus) and prawns (M. santangense) were also fed to the octopuses. Pieces of PVC pipe (50 $\mathrm{mm}$ diameter, $150 \mathrm{~mm}$ length) were supplied as shelters. The survival of the octopuses was not recorded. Other details of tank management followed Nabhitabhata et al. (2005). The average temperature during the experiment was $29.7 \pm 0.6^{\circ} \mathrm{C}$, $\mathrm{pH}$ was $8.1 \pm 0.1$ and salinity was $30.0 \pm 1.3$ psu. The photoperiod in the tanks was natural throughout the study period.

\section{Behaviour}

Aspects of octopus behaviour, such as details of life history and as information for further feed and tank management, were observed daily in live specimens. Recordings were taken in the form of drawings, still photographs and videos. The octopuses in all tanks were observed during the planktonic phase. After settlement, 175 octopus were randomly selected every $3 \mathrm{~h}$ daily and observed for a period of $2 \mathrm{~h}$.

\section{Feeding and growth}

The numbers of individuals of live food organisms were recorded daily before feeding and their weight was calculated from the average figures previously obtained from a sample of 50 individuals. Only weight was recorded for the dead food.

The feeding rate and gross food conversion efficiency were determined every 10 days $(\mathrm{N}=153$ individuals) and calculated according to Choe (1966a, b):

$$
\begin{aligned}
\mathrm{FR} & =[\mathrm{F} /(\mathrm{tW})] \times 100 \\
\mathrm{GFCE} & =\left(\mathrm{W}_{2}-\mathrm{W}_{1}\right) / \mathrm{F} \times 100
\end{aligned}
$$

where FR is feeding rate $\left(\% \mathrm{~d}^{-1}\right)$, GFCE is gross food conversion efficiency (\%), $\mathrm{F}$ is total food consumed on a wet weight basis (g), W is average weight ( $\mathrm{g}$ ) during time period $\mathrm{t}, \mathrm{W}_{1}$ is initial weight $(\mathrm{g}), \mathrm{W}_{2}$ is final weight $(\mathrm{g})$, and $\mathrm{t}$ is number of days (10-day period).

Growth was determined every $10 \mathrm{~d}$ in terms of the gain in dorsal mantle length (ML, mm) and wet body weight $(\mathrm{W}, \mathrm{g})(\mathrm{N}=153)$. Ten octopuses were sampled from each tank and their activity during measurement and weighing was reduced by decreasing the water depth in the container. The instantaneous rates of relative growth (IGR) in both ML (IGRL, \%) and weight (IGRW, \%) were calculated according to Forsythe (1984) and Forsythe and Van Heukelem (1987):

$$
\begin{gathered}
\mathrm{IGRL}=\left[\left(\ln \mathrm{ML}_{2}-\ln \mathrm{ML}_{1}\right) / \mathrm{t}\right] \times 100 \\
\mathrm{IGRW}=\left[\left(\ln _{2}-\ln \mathrm{W}_{1}\right) \mathrm{t}\right] \times 100
\end{gathered}
$$

where $\mathrm{ML}_{1}$ is the initial mantle length $(\mathrm{mm})$ and $\mathrm{ML}_{2}$ is the final mantle length $(\mathrm{mm})$.

The body weight-mantle length was expressed using a power regression model $(\mathrm{N}=153)$. The mantle length-age relationship was expressed by an exponential regression model in the early growth phase $(\mathrm{N}=47)$ and a cubic regression model in the following phase $(\mathrm{N}=87)$. Three different types of model were used to fit the weight-age relationship, exponential regression $(\mathrm{N}=38)$, power regression $(\mathrm{N}=40)$ and quadratic regression $(\mathrm{N}=63)$.

$$
\begin{gathered}
\mathrm{W}=\mathrm{a}_{1} \mathrm{ML}^{\mathrm{b}} \mathrm{L}^{1} \\
\mathrm{ML}=\mathrm{a}_{2} \mathrm{e}^{\mathrm{b} \mathrm{A}} \\
\mathrm{ML}=\mathrm{a}_{3}+\mathrm{b}_{3} \mathrm{~A}+\mathrm{b}_{4} \mathrm{~A}^{2}+\mathrm{b}_{5} \mathrm{~A}^{3} \\
\mathrm{~W}=\mathrm{a}_{4} \mathrm{e}^{\mathrm{b} 6 \mathrm{~A}} \\
\mathrm{~W}=\mathrm{a}_{5} \mathrm{~A}^{\mathrm{b7}} \\
\mathrm{W}=\mathrm{a}_{6}+\mathrm{b}_{8} \mathrm{~A}+\mathrm{b}_{9} \mathrm{~A}^{2}
\end{gathered}
$$

where $\mathrm{a}_{1}, \mathrm{a}_{2}, \ldots \mathrm{a}_{\mathrm{n}}$ and $\mathrm{b}$ are constants and $\mathrm{A}$ is the age (d).

\section{RESULTS}

\section{Eggs}

The egg capsule is single, with a rice-grain shape and a fine stalk attaching it to the festoon (Fig. 3). Clusters of eggs are attached together forming a strand of eggs. The size of each egg capsule was $3.17 \pm 0.06$ $\mathrm{mm}(\mathrm{N}=360)$ along its major axis and $1.25 \pm 0.04 \mathrm{~mm}$ along its minor axis and the weight was $0.19 \pm 0.01 \mathrm{mg}$. The newly laid capsule is opaque white and after $5 \mathrm{~d}$ it gradually turns more transparent until the embryo becomes visible.

The egg is telolecithal. Eight-cell cleavage was observed at $13 \mathrm{~h}$ after fertilization. Organogenesis occurred from $129 \mathrm{~h}$ (day 5). The first inversion of the embryo was observed from $137 \mathrm{~h}$ (day 5), turning 

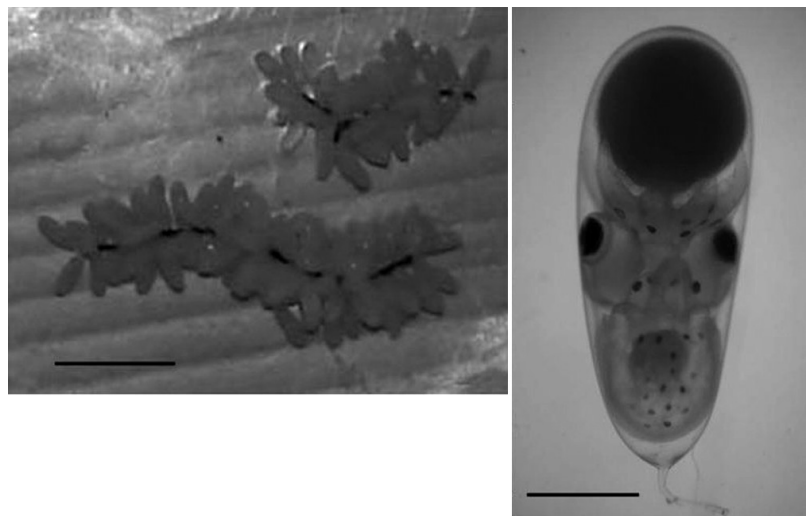

FIG. 3. - Egg string (left) and egg capsule (right) of Amphioctopus aegina with embryo at stage $23,275 \mathrm{~h}$ (scale bars: 10 and $1 \mathrm{~mm}$, respectively).

the posterior mantle towards the stalk of the capsule in head-up position. The red colour of the retina was observed from $190 \mathrm{~h}$ (day 7). Chromatophores were observed from $227 \mathrm{~h}$ and the black retina and an ink sac from $238 \mathrm{~h}$ (day 9). The second reversion was from 335 $\mathrm{h}$ (day 13), when the embryo inverted to its original position with its head towards the stalk of the capsule, corresponding to the hatching position. The first hatching occurred at $385 \mathrm{~h}$ (day 16) (Fig. 4).

The embryonic phase had an average duration of $18.3 \pm 0.6 \mathrm{~d}\left(\right.$ range $16-22 \mathrm{~d}, \mathrm{~N}=20$ ) at $29.7 \pm 0.6^{\circ} \mathrm{C}$. Hatching mostly occurred at night. The hatching period of the eggs in the same cluster of a single female continued for a period of 3-8 $\mathrm{d}$ from the first to the last egg.

\section{Behaviour}

The hatchling was planktonic, hovering headdown with its mantle at a $45^{\circ}$ angle to the tank bottom. Feeding was observed immediately after hatching. The hovering position was also the ambushing position of the hatchlings for a dart-motion to attack passing prey. Their colour pattern turned from transparent to a darker one during the hunting mode of behaviour. Prey was seized using the arms, which, in hatchlings, were each equipped with 7 suckers. The internal yolk sac was capable of sustaining unfed hatchlings for at least $5 \mathrm{~d}$.

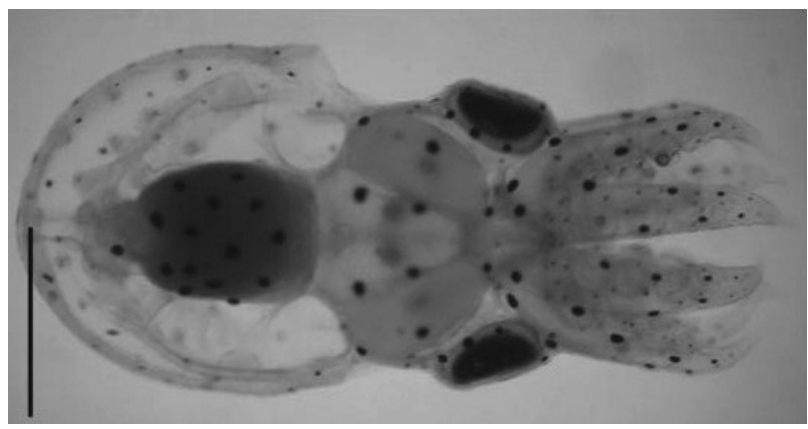

FIG. 4. - Hatchling of marbled octopus, Amphioctopus aegina (scale bar: $1 \mathrm{~mm})$

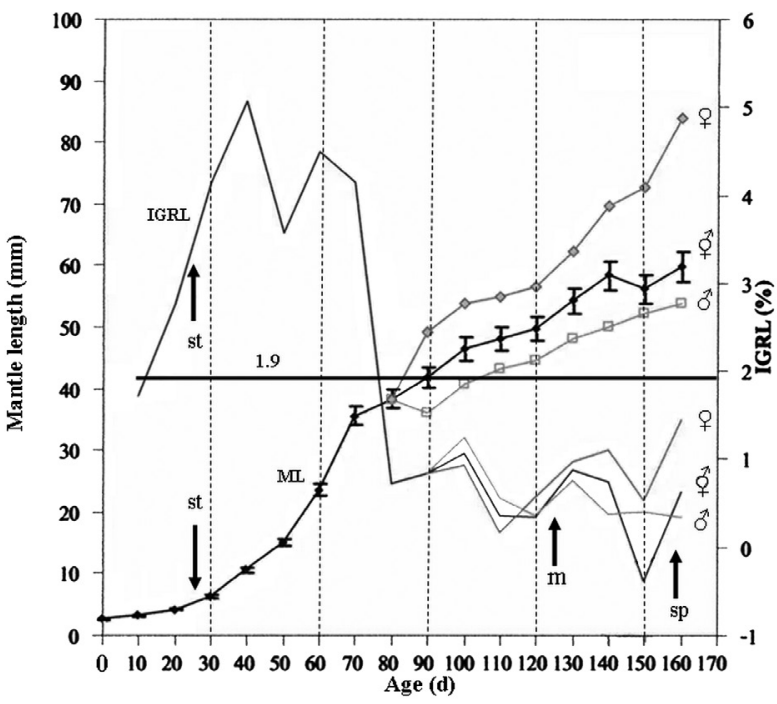

FIG. 5. - Growth in terms of mantle length (plotted lines, ML: mm), the instantaneous relative growth rate (continuous lines, IGRL: \%) and age (d) after hatching. The horizontal line with figure indicates the average value for IGRL. Arrows indicate settlement (st), mating (m) and spawning (sp).

The planktonic phase lasted 20-25 d and the octopuses subsequently entered their settling stage. From day 15 , the early settlers adopted the habit of temporarily attaching themselves to the tank wall and gradually, with a longer period of attachment, increased the depth of attachment down to the tank bottom. During the transitional settlement period, the depth of attachment was gradually increased by $50 \mathrm{~mm} / \mathrm{d}$, approximately. The young still ambushed their prey in the water column during this transitional period. The last group of settlers entered the benthic stage and fed on benthic prey after $30 \mathrm{~d}$. Crepuscular behaviour was exhibited after

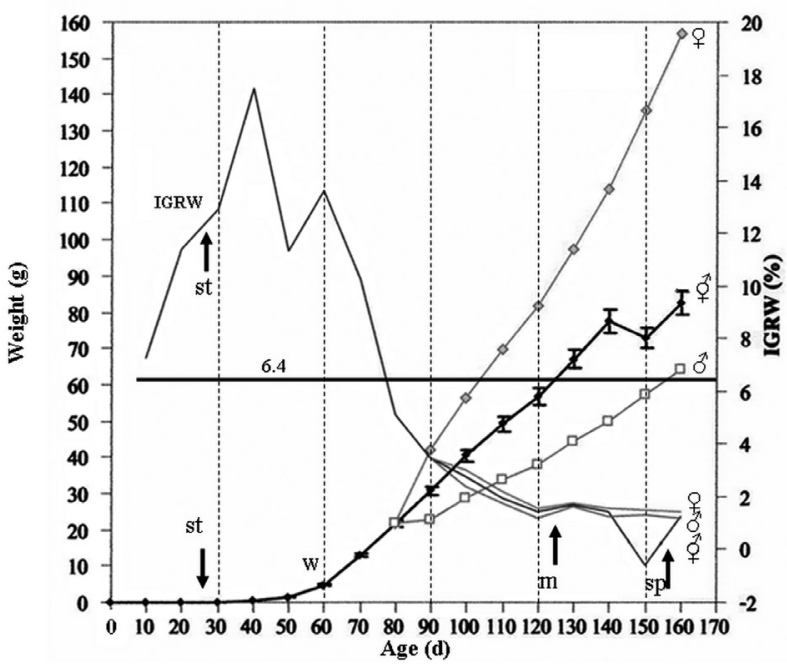

FIG. 6. - Growth in terms of weight (plotted lines, W: g), instantaneous relative growth rate (continuous lines, IGRW: \%) and age (d) after hatching. The horizontal line with figure indicates the average value for IGRW. Arrows indicate settlement (st), mating (m) and spawning (sp). 


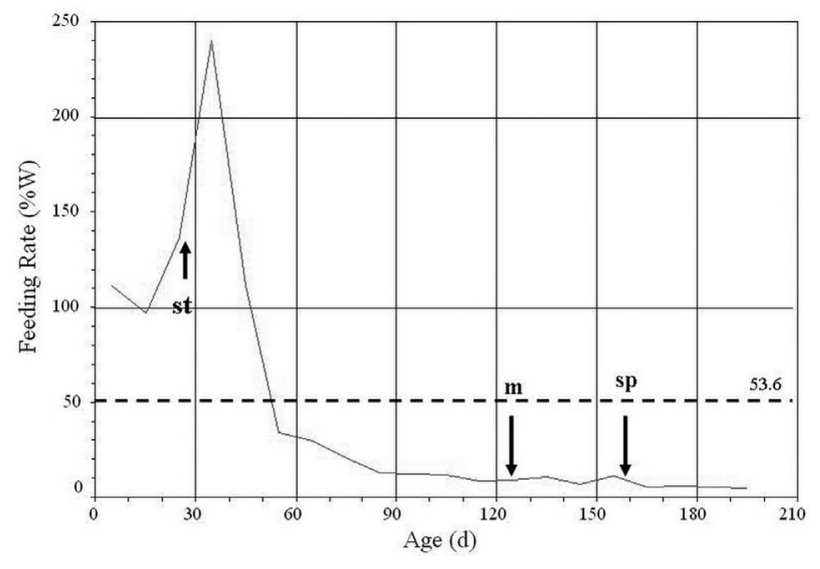

FIG. 7. - Feeding rate (\% weight) during the growth at age (d) after hatching. Arrows indicate settlement (st), mating (m) and spawning (sp). The horizontal dashed line with figure indicates the average value.

settlement, with small individuals living under shelters and larger individuals living in holes or 'homes'; all animals were solitary. Cannibalism was occasionally observed in the rearing tanks from hatching to about 70 d. The size difference between predator and prey was always more than $50 \%$.

\section{Feeding and growth}

Hatchlings of the marbled octopus grew from an average mantle length of $2.68 \pm 0.09 \mathrm{~mm}$ (ML) and an average weight of $0.003 \pm 0.001 \mathrm{~g}(\mathrm{~N}=500)$ to a $\mathrm{ML}$ of $6.34 \pm 0.91 \mathrm{~mm} \mathrm{ML}$ and a weight of $0.068 \pm 0.027 \mathrm{~g}$ $(\mathrm{N}=10)$ in $30 \mathrm{~d}$ (Figs. 5, 6). The instantaneous relative growth rate (IGR) during this period was $4.14 \%$ by length and $12.90 \%$ by weight. The IGR was highest between 30 and 40 d (i.e. after settlement), when it reached $5.06 \%$ by ML (Fig. 5) and $17.45 \%$ by weight (Fig 6). After that, IGR rapidly decreased to achieve relative stability after 80 days, when maturity was reached because

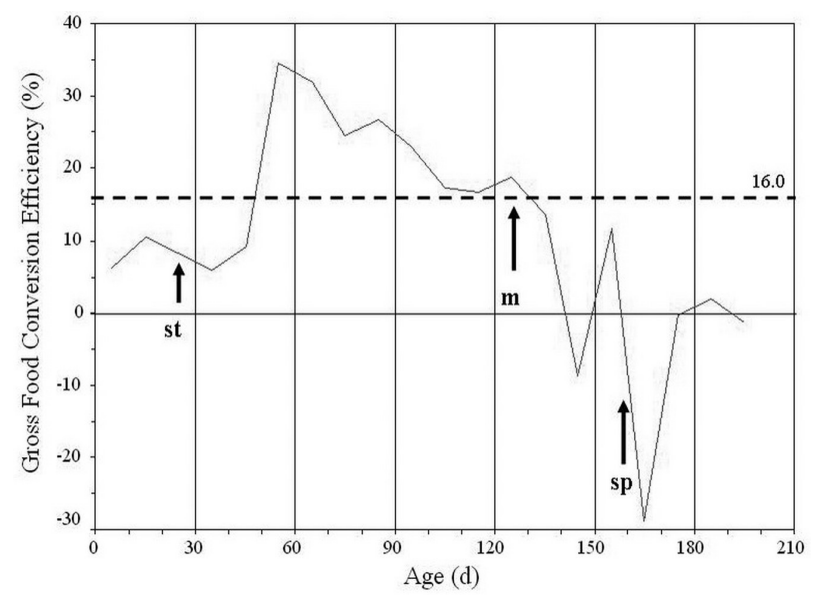

FIG. 8. - Gross food conversion efficiency (GFCE: \%) during the growth at age (d) after hatching. Arrows indicate settlement (st), mating $(\mathrm{m})$ and spawning (sp). The horizontal dashed line with figure indicates the average value.

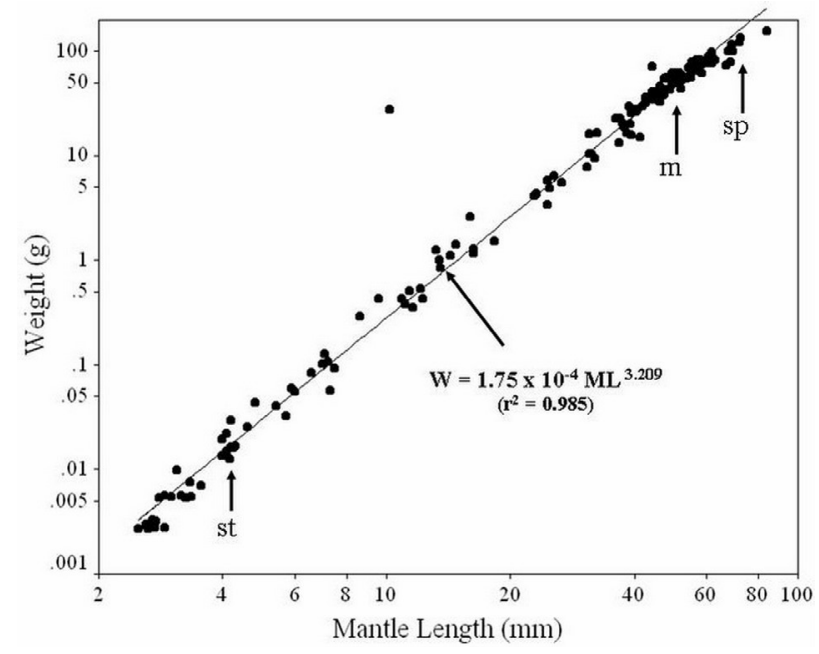

FIG. 9 . - Relationship between mantle length $(\mathrm{mm})$ and weight $(\mathrm{g})$ of Amphioctopus aegina. Arrows indicate settlement (st), mating (m) and spawning (sp).

the male hectocotylus was recognized. The average IGR from hatching to 140 days of age was $1.94 \pm 1.78 \%$ in ML and $6.41 \pm 5.60 \%$ in weight $(\mathrm{N}=14)$.

Food consumption of the octopus averaged $53.60 \pm 67.13 \%$ body weight. $\mathrm{d}^{-1}(\mathrm{~N}=14)$. The feeding rate peaked at $239.9 \%$ after $30-40 \mathrm{~d}$, at settlement, and then rapidly decreased to $12.8 \%$ at $80-90 \mathrm{~d}$, as the animals entered maturity (Fig. 7). In contrast to the feeding rate, the food conversion efficiency decreased from $6.2-10.58 \%$ in the planktonic stage to $5.86 \%$ at settlement. The peak efficiency was $31.9-34.6 \%$ at $50-70 \mathrm{~d}$, when the animals were entering maturity (Fig. 8), and then decreased to $10.5 \%$ at $140 \mathrm{~d}$ of age. The average efficiency from hatching to $140 \mathrm{~d}$ was16.04 $10.98 \%$ (range 5.86-34.59, $\mathrm{N}=14$ ).

The relationship between the mantle length $(\mathrm{mm})$ and weight (g) from hatching to $210 \mathrm{~d}$ could be expressed as a power regression (Fig. 9):

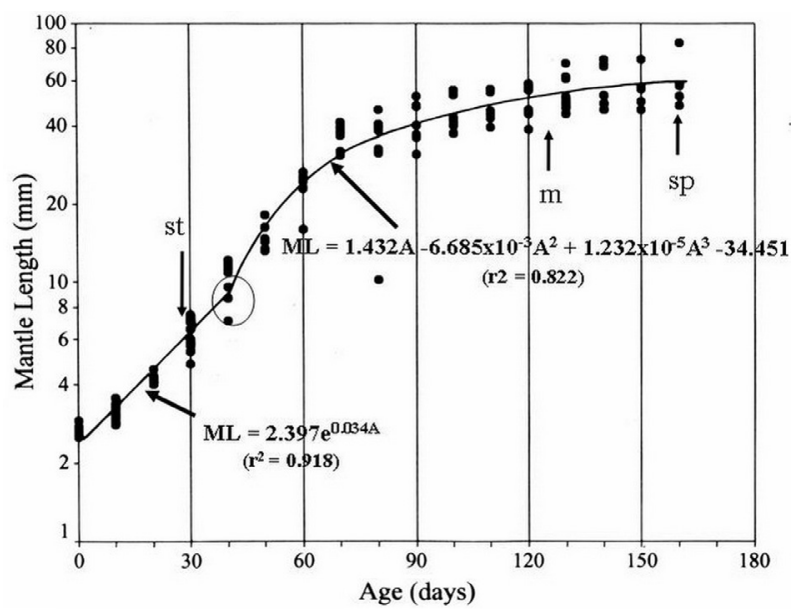

FIG. 10. - Relationships between mantle length (mm) and age (days) after hatching of Amphioctopus aegina. Arrows indicate settlement (st), mating (m) and spawning (sp). The circle indicates the inflection point. 


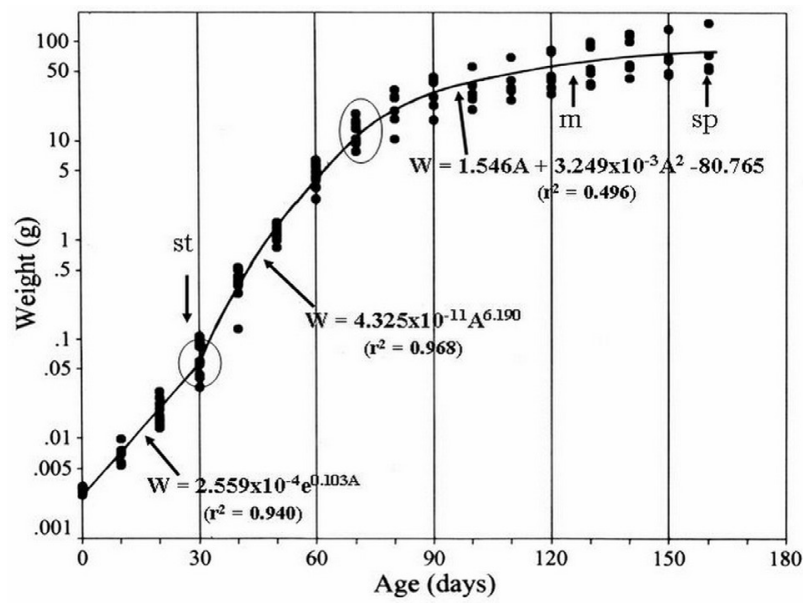

FIG. 11. - Relationships between weight (g) and age (days) after hatching of Amphioctopus aegina. Arrows indicate settlement (st), mating $(\mathrm{m})$ and spawning (sp). The circles indicate the inflection points.

$$
\begin{gathered}
\mathrm{W}=2.000 \times 10^{-3} \mathrm{ML}^{3.227} \\
\left(r^{2}=0.995, \mathrm{n}=153\right)
\end{gathered}
$$

The relationship between mantle length $(\mathrm{mm})$ and age $(d)$ could be described by an exponential model in the early phase (0-40 d; planktonic stage, hatching to early settlement) and by a cubic regression model in the second phase $(40-160 \mathrm{~d})$. The inflection point was at 40 d. (Fig. 10):

$$
\begin{gathered}
\mathrm{ML}=2.342 \mathrm{e}^{0.035 \mathrm{~A}} \\
\left(r^{2}=0.924, \mathrm{n}=47\right) \text { and } \\
\mathrm{ML}=1.607 \mathrm{~A}-\begin{array}{c}
4.000 \times 10^{-3} \mathrm{~A}^{2}+2.100 \times 10^{-5} \mathrm{~A}^{3}-41.650 \\
\left(r^{2}=0.842, \mathrm{n}=87\right)
\end{array}
\end{gathered}
$$

The relationship between weight $(\mathrm{g})$ and age $(\mathrm{d})$ was also exponential in the planktonic phase (0-30 d; planktonic to settling stages), and later could be expressed by a power regression model (30-70 d; early benthic stage) and by a quadratic regression model in the following phase (70-160 d or from maturity). The inflection points were at 30 and $70 \mathrm{~d}$. (Fig. 11):

$$
\begin{gathered}
\mathrm{W}=2.400 \times 10^{-3} \mathrm{e}^{0.106 \mathrm{~A}} \\
\left(r^{2}=0.945, \mathrm{n}=38\right) \\
\mathrm{W}=4.300 \times 10^{-11} \mathrm{~A}^{6.190} \\
\left(r^{2}=0.968, \mathrm{n}=40\right) \\
\text { and } \mathrm{W}=1.545 \mathrm{~A}-3.200 \times 10^{-3} \mathrm{~A}^{2}-80.765 \\
\left(r^{2}=0.805, \mathrm{n}=63\right)
\end{gathered}
$$

\section{Mating and spawning}

Mating was observed from an average of 125.4 $\pm 15.3 \mathrm{~d}(\mathrm{~N}=5)$ after hatching. At this stage, females had reached $54.72 \pm 1.83 \mathrm{~mm} \mathrm{ML}$ and $75.31 \pm 12.92 \mathrm{~g}$ weight $(\mathrm{N}=5)$ and males had reached $47.03 \pm 2.20 \mathrm{~mm} \mathrm{ML}$ and 45.16 $\pm 3.96 \mathrm{~g}$ weight $(\mathrm{N}=5)$. Pair formation prior to mating was not observed. The mating behavioural sequence followed 1 of 2 patterns. The first one was by tactile contact or by an enveloping pattern (Fig. 12a). The male displayed a dark brown colour pattern on half of his mantle, approached the female in her home, then mounted and spread his arm-web umbrella to envelop the female. The female covered her own mantle with her arm-web umbrella, facing (suckers outward) towards the male. The male displayed a dark brown colour and then probed his hectocotylus into the female mantle cavity. Copulation took 7-10 min. After that, the female pushed the male out of her home with her arms. If the female rejected mating, she attacked the approaching male with a rapid forward motion from her home with an attempt to envelop the male.

The second pattern was remote copulation (Fig. 12b). The male approached the female in her home, extended his hectocotylus and inserted it into the mantle cavity of the female. Copulation was without any other contact of other parts of body from both sexes. This
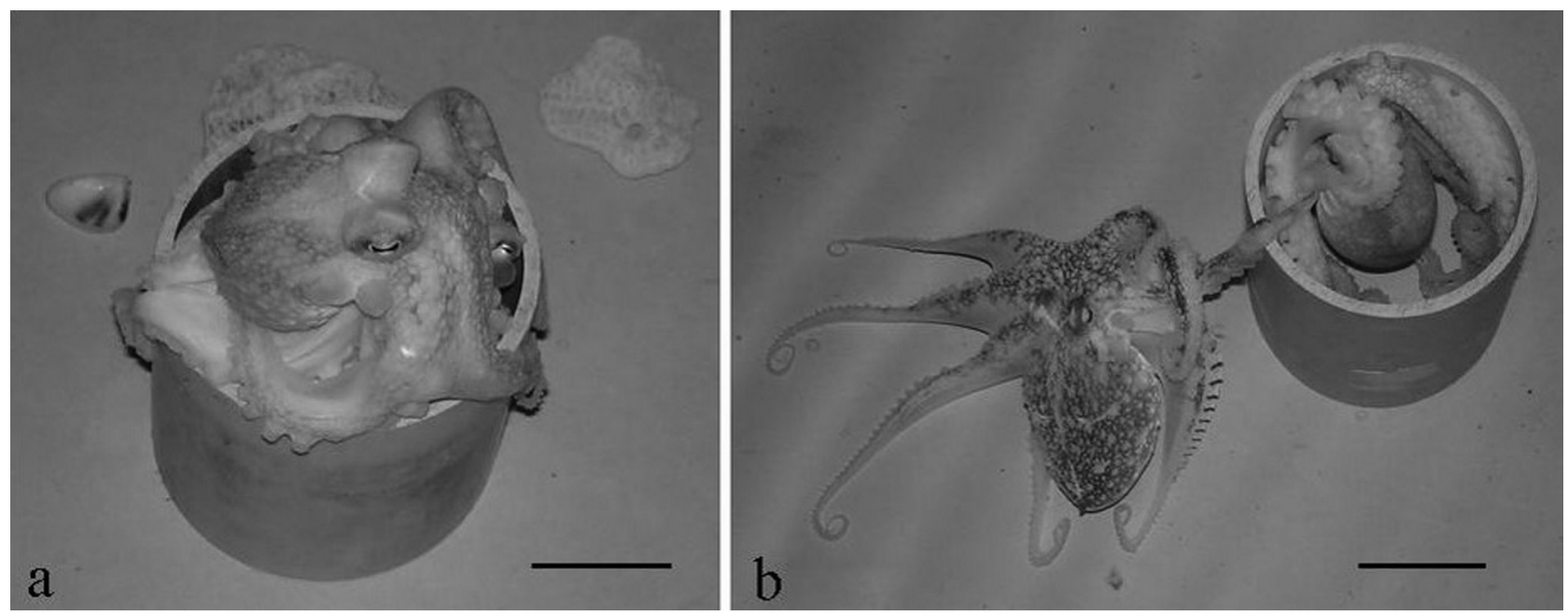

FIG. 12. - Mating behavioural pattern of Amphioctopus aegina, in the laboratory; tactile contact or enveloping pattern (a: male on top) and remote copulation pattern (b, male on left), (scale bars: $50 \mathrm{~mm}$ ). 
TABLE 1. - Comparison of the life cycle of octopus species known to produce planktonic hatchlings.

\begin{tabular}{|c|c|c|c|c|c|c|c|c|}
\hline $\begin{array}{l}\text { Species } \\
\text { Characteristics }\end{array}$ & $\begin{array}{l}\text { Enteroctopus } \\
\text { dofleini }^{a}\end{array}$ & $\begin{array}{l}\text { Macroctopus } \\
\text { maorum }^{b}\end{array}$ & $\begin{array}{l}\text { Octopus } \\
\text { bimaculatus }\end{array}$ & $\begin{array}{l}\text { Octopus } \\
\text { cyanea }^{d}\end{array}$ & $\begin{array}{l}\text { Octopus } \\
\text { mimus }^{e}\end{array}$ & $\begin{array}{l}\text { Octopus } \\
\text { tetricus }^{f}\end{array}$ & $\begin{array}{l}\text { Octopus } \\
\text { vulgaris }\end{array}$ & $\begin{array}{l}\text { Amphioctopus } \\
\text { aegina }^{h}\end{array}$ \\
\hline $\begin{array}{l}\text { Spawner size } \\
\text { (ML: mm; BW: g) }\end{array}$ & $>10000 \mathrm{~g}$ & $210 \mathrm{~mm}$ & $260 \mathrm{~g}$ & $1000-4800 \mathrm{~g}$ & $\begin{array}{l}\text { 14.9-91.8 } \\
\mathrm{mm}\end{array}$ & $1100-2400 \mathrm{~g}$ & $800-4000 \mathrm{~g}$ & $\begin{array}{l}60.5 \mathrm{~mm} \\
78.4 \mathrm{~g}\end{array}$ \\
\hline Fecundity (nos egg) & $18000-100000$ & 7000 & 20000 & $110000-700000$ & $8000-40000$ & $125-700$ & $100000-500000$ & $0 \quad 6900$ \\
\hline Egg capsule size (mm) & 6-8 & $10.8 \times 1.8$ & $3.8 \times 1.3$ & 3 & $2.2 \times 2.5$ & 3 & $2.2 \times 1.0$ & $3.2 \times 1.2$ \\
\hline $\begin{array}{l}\text { Hatchling size } \\
\text { (ML: } \mathrm{mm} \text { ) }\end{array}$ & $1.1-3.4$ & 4.42 & 2.6 & 2.5 & 0.98 & 1.5 & 1.7 & 2.7 \\
\hline Relative to adult size (\%) & - & 2.1 & 3.4 & - & 6.6 & - & 2 & 4.4 \\
\hline Sucker on arm (nos) & $3-4$ & $7-8$ & 6-7 & - & - & 3 & 3 & 7 \\
\hline $\begin{array}{l}\text { Embryonic period }(\mathrm{d}) ; \\
\left(\mathrm{T}:{ }^{\circ} \mathrm{C}\right)\end{array}$ & $160(12.8)$ & $80(11-19.4)$ & $31(19.7)$ & $28(20-36)$ & $\begin{array}{l}37-45 \\
(22.1)\end{array}$ & $\begin{array}{c}22-36 \\
(19-22.6)\end{array}$ & $\begin{array}{l}50-125(12-13) \\
47(17-19)\end{array}$ & $\begin{array}{c}14-22 \\
(28-29.7)\end{array}$ \\
\hline Hatching period (d) & $40-78$ & 10 & - & - & - & $6-28$ & - & $3-8$ \\
\hline Planktonic period (d) & $46-90$ & - & - & 30 & - & - & $33-60(20) 40(22.5$ & .5) $20-25$ \\
\hline Settling size (ML: mm) & 50 & - & - & 10 & - & - & $3.8-8.6$ & 6.3 \\
\hline Feeding rate $(\% \mathrm{BW})$ & $1.2-1.4$ & - & - & 5.7 & - & $1.5-7.6$ & $4.7-6.6$ & 53.6 \\
\hline Conversion efficiency (\%) & $39.6-74.7$ & - & - & 48 & - & $46.8(11-76)$ & $40-58.3$ & 16.0 \\
\hline $\begin{array}{l}\text { Instantaneous daily } \\
\text { growth rate }(\%)\end{array}$ & $0.7-1.1$ & - & - & $1.2-4.1 \mathrm{~W}$ & - & $0.8-6.1$ & $0.2-4.1$ & $1.9 \mathrm{ML}, 6.4 \mathrm{~W}$ \\
\hline Life span (d) & $\begin{array}{c}3-5 y \\
(1095-1825 \mathrm{~d})\end{array}$ & - & - & $\begin{array}{l}12-15 \mathrm{~m} \\
(365-455 \mathrm{~d})\end{array}$ & - & - & - & $215 \mathrm{~d}$ \\
\hline
\end{tabular}

References: a, Gabe (1975); Hartwick (1983); b, Batham (1957); c, Ambrose (1981); d, Van Heukelem (1973, 1983), Wells and Wells (1970); e, Baltazar et al. (2000), Cortez et al. (1999); f, Joll (1976, 1977, 1983); g, Boletzky (1977), Iglesias et al. (2004), Itami et al. (1963), Mangold (1983), Mangold and Boletzky (1973), Villanueva (1995); h, Ignatius and Srinivasan (2006), Phanichpong (1985), present study.

pattern of copulation took 3-5 min. Other behaviour observed before and after copulation was similar to the enveloping pattern.

The interval between mating and spawning averaged $32.3 \pm 12.9 \mathrm{~d}$ (range $20-40 \mathrm{~d}$ ). On the day of spawning, the female did not leave her home for feeding. An egg cluster was cradled in her arm web behind her mantle. The female regularly cleaned and aerated her egg clusters with her arms and directed jets of water from her funnel. Some brooding females initiated premature hatching of her eggs by a strong and rapid exhalent jetting and shaking of egg clusters with her arms after being disturbed by sudden visual stimuli (i.e. approach of tank-cleaning devices). Cessation of food intake by the brooding female was observed until hatching and, in most cases, until her death. Some females fed for 1 to $2 \mathrm{~d}$ after hatching before ceasing. The average number of eggs laid by a single female octopus was $6900.0 \pm 1417.7$ eggs $(\mathrm{N}=20)$.

\section{Lifespan}

Females died within 17.0 $\pm 8.6 \mathrm{~d}$ after the hatching of the eggs. The male died within a few days after the female. The average lifespan of the female was $192.0 \pm 13.5$ $\mathrm{d}$ (161-204) and that of the male was $232.8 \pm 17.6 \mathrm{~d}$ (214255). When the embryonic period was included, the life span of the female, male and both sexes combined was 202.2 $\pm 19.1 \mathrm{~d}(179-222)$ and 242.5 $\pm 22.1 \mathrm{~d}(222-273)$ and 222.4 \pm 28.8 (179-273), respectively.

\section{DISCUSSION}

Among octopods that produce planktonic offspring, A. aegina is of moderate body size and fecundity compared to other species (Table 1). Other species spawn at a body weight of more than $1000 \mathrm{~g}$ and with a fecundity of more than 10000 eggs, except for Octopus bimaculatus Verrill and Macroctopus maorum (Hutton). The size of the egg capsule and hatchlings falls into the medium range, compared with $O$. vulgaris Cuvier and $M$. maorum. The mantle length of hatchlings of A. aegina, 3.05 $\mathrm{mm}$ according to Ignatius and Srinivasan (2006) and 2.7 $\mathrm{mm}$ in this study, is approximately $4.4 \%$ of the adult $\mathrm{ML}$ and falls within the 2-5\% range of the small-size-octopus category, as suggested by Boletzky (1977) when compared with the larger size of the benthic hatchlings, $6-20 \%$ of the adult length. The number of suckers on each arm of A. aegina, 7, also corresponds to the category of "small hatchlings" with 3-10 suckers per arm (Boletzky, 1977) compared with more than 20 suckers for the "large hatchlings". Only life histories of the taxa with planktonic hatchlings are further discussed here. The comparison between species of temperate-large and

TABLE 2. - Comparison of the life cycle characteristics of reared benthic cephalopods in relation to age (d) and daily growth (\%).

\begin{tabular}{|c|c|c|c|c|}
\hline Life cycle & $\begin{array}{c}\text { Sepia } \\
\text { pharaonis }\end{array}$ & $\begin{array}{l}\text { Sepiella } \\
\text { inermis }^{\mathrm{b}}\end{array}$ & $\begin{array}{l}\text { Euprymna } \\
\text { hyllebergic }\end{array}$ & $\begin{array}{c}\text { Amphioctopus } \\
\text { aegina }^{\mathrm{d}}\end{array}$ \\
\hline $\begin{array}{l}\text { Embryonic } \\
\text { phase (d) }\end{array}$ & 14 & 13 & 14 & 18 \\
\hline $\begin{array}{l}\text { Planktonic } \\
\text { phase }(\mathrm{d})\end{array}$ & - & 3 & 0.8 & 20 \\
\hline Settlement (d) & 0 & 5 & 25 & 30 \\
\hline Mating (d) & 90 & 70 & 66 & 125 \\
\hline Spawning (d) & 110 & 87 & 94 & 158 \\
\hline $\begin{array}{l}\text { Reproductive } \\
\text { phase (d) }\end{array}$ & 44 & 46 & 33 & 73 \\
\hline Daily growth & 1.37 & 2.43 & 2.41 & 1.94 \\
\hline$(\% \mathrm{~W})$ & 3.40 & 5.54 & 7.51 & 6.41 \\
\hline Life span (d) & 149 & 116 & 99 & 215 \\
\hline
\end{tabular}

References: a, Nabhitabhata and Nilaphat (1999); b, Nabhitabhata (1997), Nabhitabhata (2002); c, Nabhitabhata et al. (2005); d, present study. 
TABLE 3. - Comparison on the longevity of the stages of the life history of reared benthic cephalopods as a percentage of their lifespan. (Numbers in parentheses are estimated longevity when the embryonic phase is included in the life span).

\begin{tabular}{lcccc}
\hline $\begin{array}{l}\text { Life cycle } \\
\text { phases }\end{array}$ & $\begin{array}{c}\text { Sepia } \\
\text { pharaonis }^{\mathrm{a}}\end{array}$ & $\begin{array}{c}\text { Sepiella } \\
\text { inermis }^{\mathrm{b}}\end{array}$ & $\begin{array}{c}\text { Euprymna Amphioctopus } \\
\text { hyllebergi }^{\mathrm{c}}\end{array}$ & $\begin{array}{c}\text { Aegina } \\
\text { d }^{\mathrm{d}}\end{array}$ \\
\hline Embryonic phase & $(8.6)$ & $(10.1)$ & $(12.4)$ & $(7.7)$ \\
Planktonic phase & - & 2.6 & 0.3 & 9.3 \\
Settlement & 0 & 4.3 & 22.1 & 14.0 \\
Mating & 60.4 & 60.3 & 58.4 & 58.1 \\
Spawning & 73.8 & 75.0 & 83.2 & 73.5 \\
Reproductive phase & 29.5 & 39.7 & 29.2 & 34.0 \\
Life span & 100.0 & 100.0 & 100.0 & 100.0 \\
\hline
\end{tabular}

References: a, Nabhitabhata and Nilaphat (1999); b, Nabhitabhata (1997), Nabhitabhata (2002); c, Nabhitabhata et al. (2005); d, present study.

tropical-moderate size reveals that there are similarities in many aspects of their life cycle irrespective of either their habitats or size at maturity.

The planktonic period, hatching to settlement, was approximately $30-40 \mathrm{~d}$ in most of the species and a week shorter in A. aegina in this study (Table 1). A lower temperature $\left(20^{\circ} \mathrm{C}\right)$ prolonged the period in larger species, O. vulgaris (Villanueva, 1995) and Enteroctopus dofleini (Hartwick, 1983). The shortest period, $14 \mathrm{~d}$, was recorded for $O$. rex at $27.5^{\circ} \mathrm{C}(\mathrm{Na}-$ bhitabhata et al., 2003). Although it was comparable to $20 \mathrm{~d}$ at $29.7^{\circ} \mathrm{C}$ for $A$. aegina in this study, it might also be species-specific. However, the similar size at settlement of approximately 4-10 mm ML (Table 1) in all species suggests that the duration of the period before settlement is less important than the actual size at settlement.

The daily feeding rates in temperate octopods were less than $10 \%$ at $20-25^{\circ} \mathrm{C}$ compared with the approximately $53.6 \%$ of $A$. aegina in this study. The lower feeding rates yielded higher conversion efficiencies, of approximately $60-75 \%$ in temperate compared with
$16.0 \%$ in tropical A. aegina. However, the instantaneous daily growth rate, by weight, of A. aegina had a maximum value of $17.5 \%$, much higher than the values of less than $10 \%$ for other species (Table 1).

The food conversion efficiency was lower in the planktonic phase than in the following phase, showing an opposite trend to the difference in feeding rate (Fig. 7, 8) and revealing a high energy cost for the planktonic mode of the paralarvae. The conversion efficiency peaked from the age of 60-70 d to 120-130 $\mathrm{d}$, a period of $65 \mathrm{~d}$ before mating was observed at the age of $125 \mathrm{~d}$. This two-month period indicates that the process of energy storage for subsequent reproduction required a relatively long period in A. aegina, because it takes as long as $27.9 \%$, approximately one-third, of its lifespan, which is similar to the value of $34 \%$ (73 d) for the reproductive phase itself (Table 2, 3).

The daily growth rate was notably similar among the different benthic cephalopods, at approximately $2 \%$ in terms of mantle length and 3-7\% in weight (Table 2). The present study supports the idea that the growth pattern could not be fitted by one single model throughout the entire life cycle because a single model will not properly describe the growth during early or late life (Forsythe and Van Heukelem, 1987). Such patterns were also reported in other tropical benthic cephalopods, e.g. S. inermis (Nabhitabhata, 2002) and E. hyllebergi (Nabhitabhata et al., 2005). These species showed 2 phases of growth during the life cycle (expressed by 2 models), when considered in terms of either mantle length or body weight. The present study also supports the statement by Forsythe and Van Heukelem (1987) that the description of growth at the intersection of the 2 equations is often not accurate. We found that adding a third model for the early settling phase of A. aegina could yield a better fit overall for the growth pattern over the course of the life cycle. However, the precise form of the models estimated

TABLE 4. - Benthic octopods, inhabiting Thai waters, known to produce planktonic hatchlings ( $\mathrm{H}$, from rearing experiment) or assumed to do so due to producing small-type eggs (E, according to Boletzky 1974, 1977, 1978-1979).

\begin{tabular}{|c|c|c|}
\hline Taxa & Inference & References \\
\hline \multicolumn{3}{|l|}{ From rearing experiment } \\
\hline Amphioctopus rex & $\mathrm{H}$ & Nabhitabhata et al. (2003) \\
\hline A. membranaceus & $\mathrm{H}$ & Nabhitabhata (1985) \\
\hline A. neglectus & $\mathrm{H}$ & Nabhitabhata(unpublished data) \\
\hline A. aegina & $\mathrm{H}$ & present study \\
\hline Cistopus indicus & $\mathrm{H}$ & Nabhitabhata (1995) \\
\hline Hapalochlaena cf. maculosa & $\mathrm{H}$ & Nabhitabhata (1995) \\
\hline Octopus cf. kaurna & $\mathrm{H}$ & Nabhitabhata(unpublished data) \\
\hline Octopus cyanea & $\mathrm{H}$ & Van Heukelem (1973) \\
\hline O. cf. vulgaris & $\mathrm{H}$ & $\begin{array}{l}\text { Boletzky (1977), Mangold (1983), Mangold and Boletzky (1973), } \\
\text { Villanueva (1995), Iglesias et al. (2004) }\end{array}$ \\
\hline \multicolumn{3}{|l|}{ From ovary investigation } \\
\hline Amphioctopus exannulatus & $\mathrm{E}$ & Norman (1992a: Villanueva and Norman 2008) \\
\hline A. marginatus & $\mathrm{E}$ & Norman (1992b: Villanueva and Norman 2008) \\
\hline A. siamensis & $\mathrm{E}$ & Nateewathana and Norman (1999) \\
\hline Callistoctopus luteus & $\mathrm{E}$ & Norman and Sweeney (1997) \\
\hline C. ornatus & $\mathrm{E}$ & Norman (1993: Villanueva and Norman 2008) \\
\hline O. cf. niveus & $\mathrm{E}$ & Nateewathana (1997) \\
\hline O. parvus & $\mathrm{E}$ & Sasaki (1929) \\
\hline Thaumoctopus mimicus & $\mathrm{E}$ & Norman and Hochberg (2005b) \\
\hline
\end{tabular}


in this study might be species-specific and applicable only for octopuses in captivity, since the growth and life span of the octopus may be modified in captivity. Outliers in the models obtained are genuine points and not mistakes, which might be because of mutations or other unknown conditions in aquaculture. Those octopuses could survive in rearing tanks at least to the time of the latest growth measurement, but might not be able to do so in the wild.

One notable characteristic is the egg brooding behaviour, which involved cradling egg strings on the arm web of the female octopods in Thai waters. This characteristic has been observed in reared $O$. membranaceus Quoy and Gaimard (Nabhitabhata, 1985), $A$. neglectus (Nateewathana and Norman) and $O$. cf. kaurna Stranks (Nabhitabhata, unpublished data), A. rex (Nateewathana and Norman) (Nabhitabhata et al., 2003), A. aegina (present study), Cistopus indicus (Rapp), and H. cf. maculosa (Nabhitabhata, 1995). The above-mentioned species all produce planktonic hatchlings. Egg cradling seems to be a common characteristic among octopods in Thai waters but it contrasts with what is seen in most species of octopods with planktonic hatchlings, which attach their egg strings to hard substrates (Villanueva and Norman, 2008). It is possible that the absence of preferred substrates in captivity might cause the octopus to cradle their egg strings instead of attaching them.

Rocha et al., (2001) proposed simultaneous terminal spawning as one of the cephalopod reproductive strategies. The representative species for this strategy include 3 benthic octopods, $O$. cyanea, $O$. mimus and $O$. vulgaris. Although the reproductive behaviour and growth observed in this study indicates that spawning of $A$. aegina is terminal, further investigation on the oocyte maturation is required to fully characterize its reproductive strategy.

Thai waters, particularly in the Gulf of Thailand, are shallow (maximum depth $90 \mathrm{~m}$ with an average depth of about $30 \mathrm{~m}$ ) with a fluctuating tropical environment (a long rainy season of at least $6 \mathrm{~m}$ and, consequently, a heavy freshwater discharge). A notable feature is that 17 of the 19 species of benthic octopods recorded from Thai waters (Nabhitabhata, 1999) are known or tend to reproduce planktonic hatchlings (Table 4). Rocha et al., (2001) also proposed that the strategy of simultaneous terminal spawning is adapted to extremely unstable environments. The 3 representative octopods of this strategy are known to reproduce planktonic hatchlings (Table 1). Two of them, O. cyanea and O. vulgaris, are also recorded in Thai waters (Table 4). This suggests that reproducing planktonic hatchlings is the reproductive strategy relevant to simultaneous terminal spawning in a neritic-fluctuating or unstable environment of benthic octopods.

The lifespan of the tropical A. aegina in this study,

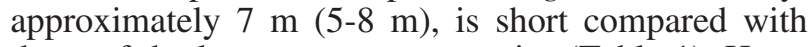
those of the larger temperate species (Table 1). However, when compared wth other medium-size tropical benthic cephalopods (Table 2), it is around 0.4-1.2 times as long. Although the period from hatching to complete settlement of A. aegina, is comparable to that of E. hyllebergi, after that the period to reach maturity is about twice as long. The neritic-benthic cephalopods also display consistent features in their reproductive phase. The longevity from hatching to maturity is about $60 \%$ to mating and $70-80 \%$ to spawning and the reproductive phase is about $30 \%$, one-third of the lifespan (Table 3).

Overall, the life cycle of $A$. aegina is similar to that of other benthic octopods, with similar reproductive strategies in terms of its characteristics and habits in the embryonic, planktonic and settling phases. However, the growth pattern observed, which includes a single phase during transitional settlement, was determined under captive rearing conditions and might be modified from what occurs in the wild. The similarity of the duration of different phases of the life span of $A$. aegina compared with other benthic cephalopods with planktonic hatchlings indicates that they have adapted to a similar way of life although their niches overlap. The similarities among these benthic cephalopod taxa attest to the fitness of their life-history strategy of reproducing planktonic offspring.

\section{ACKNOWLEDGEMENTS}

The authors thank the staff of the Rayong Coastal Fisheries Research and Development Centre, Department of Fisheries, the Centre for Biodiversity of Peninsular Thailand and the Department of Biology, Faculty of Science, Prince of Songkla University, Thailand for their invaluable assistance and the use of facilities for the experiments. We also wish to gratefully acknowledge Professor Graham J. Pierce (University of Aberdeen, UK), Dr. Roger Villanueva (Institut de Ciencies del Mar, Spain), Dr. Angel Guerra (Instituto de Investigaciones Marinas, Spain) and the anonymous reviewer for their many helpful suggestions and comments resulting in a substantial improvement to the quality of the manuscript.

\section{REFERENCES}

Ambrose, R.F. 1981. - Observations on the embryonic development and early post-embryonic behavior of Octopus bimaculatus (Mollusca: Cephalopoda). Veliger, 24: 139-146.

Baltazar, P., P. Rodríguez, W. Riveray and V. Valdivieso. - 2000. Experimental culture of Octopus mimus Gould, 1852 in Peru. Rev. Peru Biol., 7: 151-160.

Batham, E.J. - 1957. Care of eggs by Octopus maorum. Trans. R. Soc. N.Z., 84: 629-638.

Boletzky, S.v. - 1974. The "larvae" of Cephalopoda: a review. Thalassia Jugosl., 10: 45-76.

Boletzky, S.v. - 1977. Post-hatching behaviour and mode of life in cephalopods. Symp. Zool. Soc. Lond., 38: 557-567.

Boletzky, S.v. - 1978-1979. Nos connaissances actuelles sur le developpement des octopodes. Vie Milieu, 28-29: 85-120.

Boyle, P. and P. Rodhouse. - 2005. Cephalopods Ecology and Fisheries. Blackwell Science, Oxford.

Choe, S. - 1966a. On the eggs, rearing, habits of the fry, and growth of some Cephalopoda. Bull. Mar. Sci., 16: 330-348. 
Choe, S. - 1966b. On the growth, feeding rates and the efficiency of food conversion for cuttlefishes and squids. Korean J. Zool., 9: 72-80.

Cortez, T., A.F. Gonzalez and A. Guerra. - 1999. Growth of cultured Octopus mimus (Cephalopoda, Octopodidae). Fish. Res., 40: 81-89.

DeRusha, R.H., J.W. Forsythe and R.T. Hanlon. - 1987. Laboratory growth, reproduction and life span of the Pacific pygmy octopus, Octopus digueti. Pac. Sci., 41: 104-121.

Forsythe, J.W. - 1984. Octopus joubini (Mollusca: Cephalopoda): a detailed study of growth through the full life cycle in a closed seawater system. J. Zool., 202: 393-417.

Forsythe, J.W. and R.T. Hanlon. - 1980. A closed marine culture system for rearing Octopus joubini and other large-egged benthic octopods. Lab. Anim., 14: 137-142.

Forsythe, J.W. and R.T. Hanlon. - 1988. Effect of temperature on laboratory growth, reproduction and life span of Octopus bimaculoides. Mar. Biol., 98: 369-379.

Forsythe, J.W. and W.F. Van Heukelem. - 1987. Growth. In: P.R. Boyle (ed.), Cephalopod Life Cycles Volume II Comparative Reviews, pp. 135-156. Academic Press.

Gabe, S.H. - 1975. Reproduction in the giant octopus of the North Pacific, Octopus dofleini martini. Veliger, 18: 146-150.

Hanlon, R.T. - 1987. Mariculture. In: P.R. Boyle (ed.), Cephalopod Life Cycles Volume II Comparative Reviews, pp. 291-305. Academic Press.

Hanlon, R.T. and M.R. Wolterding. - 1989. Behavior, body patterning, growth and life history of Octopus briareus cultured in the laboratory. Am. Malacol. Bull., 7: 21-45.

Hartwick, B. - 1983. Octopus dofleini. In: P.R. Boyle (ed.), Cephalopod Life Cycles Volume I Species Accounts, pp. 277-291. Academic Press.

Iglesias, J., J.J. Otero, C. Moxica, L. Fuentes and F.J. Sanchez. 2004. The complete life cycle of the octopus (Octopus vulgaris, Cuvier) under culture conditions: paralarval rearing using Artemia and zoeae, and first data on juvenile growth up to 8 months of age. Aquacult. Int., 12: 481-487.

Ignatius, B. and M. Srinivasan. - 2006. Embryonic development in Octopus aegina Gray, 1849. Curr. Sci., 19: 1089-1092.

Itami, K., Y. Izawa, S. Maeda and K. Nakai. - 1963. Notes on the laboratory culture of the octopus larvae. Bull. Jap. Soc. Sci. Fish., 29: 514-520.

Joll, L.M. - 1976. Mating, egg-laying and hatching of Octopus tetricus (Mollusca: Cephalopoda) in laboratory. Mar. Biol., 36: 327-333.

Joll, L.M. - 1977. Growth and food intake of Octopus tetricus (Mollusca: Cephalopoda) in aquaria. Aust. J. Mar. Fresh. Res., 28 $45-56$.

Joll, L.M. - 1983. Octopus tetricus. In:P.R. Boyle (ed.), Cephalopod Life Cycles Volume I Species Accounts, pp. 325-334. Academic Press

Mangold, K. - 1983. Octopus vulgaris. In: P.R. Boyle (ed.), Cephalopod Life Cycles Volume I Species Accounts, pp. 335-364. Academic Press.

Mangold, K. and S.v. Boletzky. - 1973. New data on reproductive biology and growth ofOctopus vulgaris. Mar. Biol., 19: 7-12.

Nabhitabhata, J. - 1985. Mating, egg-carrying and other behavior of webfoot octopus, Octopus membranaceus Quoy \& Gaimard. Rayong Brackishwater Fisheries Station Technical Paper 6/1985: 1-20.

Nabhitabhata, J. - 1995. The culture of cephalopods: commercial scale attempt in Thailand. In: K.P.P. Nambiar and T. Singh (eds.), Aquaculture Towards the 21st Century, pp. 138-146. INFOFISH.

Nabhitabhata, J. - 1997. Life cycle of three cultured generations of spineless cuttlefish, Sepiella inermis (Ferrussac \& d'Orbigny, 1848). Phuket Mar. Biol. Cent. Spec. Pub., 17: 289-298.

Nabhitabhata, J. - 1999. Checklist of diversity and distribution of recent cephalopods from Thai waters. Thai Mar. Fish. Res. Bull., 7: 89-96.

Nabhitabhata, J. - 2002. Life History and Behaviour of Reared Neritic Cephalopods from Thai Waters. PhD thesis, Tokyo Univ. Fish.

Nabhitabhata, J. and P. Nilaphat. - 1999. Life cycle of cultured pharaoh cuttlefish, Sepia pharaonis Ehrenberg, 1831. Phuket Mar. Biol. Cent. Spec. Pub., 19: 25-40.
Nabhitabhata, J., P. Nilaphat, C. Jaroongpattananon and P. Promboon. -2003 . Culture, growth and behaviour of king octopus, Octopus rex Nateewathana and Norman, 1999. Rayong Coast. Fish. Res. Develop. Cent. Contrib., 26: 17.

Nabhitabhata, J., P. Nilaphat, P. Promboon and C. Jaroongpattananon. - 2005. Life cycle of cultured bobtail squid, Euprymna hyllebergi Nateewathana, 1997. Phuket Mar. Biol. Cent. Res. Bull., 66: 351-365.

Nateewathana, A. - 1997. The octopod fauna (Cephalopoda: Octopoda) of the Andaman Sea, Thailand. Phuket Mar. Biol. Cent. Spec. Pub., 17: 407-452.

Nateewathana, A. and M.D. Norman. - 1999. On three new species of ocellate octopuses (Cephalopoda: Octopoda) from Thai waters. Phuket Mar. Biol. Cent. Spec. Pub. 19: 445-462.

Norman, M.D. and M.J. Sweeney. - 1997. The shallow-water octopuses (Cephalopoda: Octopodidae) of the Philippines. Invertebr. Taxon., 11: 9-140.

Norman, M.D. - 1998. Octopodidae benthic octopuses. In: K.E. Carpenter and V.H. Niem (eds.), The Living Marine Resources of the Western Central Pacific Volume 2 Cephalopods, Crustaceans, Holothurians and Sharks, FAO Species Identification Guide for Fishery Purposes, pp. 800-826. Food and Agriculture Organization.

Norman, M.D. - 2000. Cephalopods, A World Guide. ConchBooks, Hackenheim.

Norman, M.D. and F.G. Hochberg. - 2005a. The current state of octopus taxonomy. Phuket Mar. Biol. Cent. Res. Bull., 66: 127-154.

Norman, M.D. and F.G. Hochberg. - 2005b. The "mimic octopus" (Thaumoctopus mimicus $\mathrm{n}$. gen. et sp.), a new octopus from the tropical Indo-West Pacific (Cephalopoda: Octopodidae). Mollusc. Res., 25: 57-70.

Phanichpong, W. - 1985. Studies on reproductive biology and some behaviors of the devil fish, Octopus dollfusi Robson, 1928. MSc thesis, Kasetsart University.

Rocha, F., A. Guerra and A.F. Gonzalez. - 2001. A review of reproductive strategies in cephalopods. Biol. Rev., 76: 291-304.

Roper, C.F.E., M.J. Sweeney and C.E. Naun. - 1984. FAO Species Catalogue. Vol. 3 Cephalopods of the World An Annotated and Illustrated Catalogue of Species of Interest to Fisheries FAO Fisheries Synopsis no. 125 Vol. 3. Food and Agriculture Organization.

Sasaki, M. - 1929. A monograph of the dibranchiate cephalopods of the Japanese and adjacent waters. J. Fac. Agri., Hokkaido Imp. Univ., suppl 20: 1-357.

Supongpan, M. - 1995. Cephalopod resource in the Gulf of Thailand. In: J. Nabhitabhata (ed.), Biology and Culture of Cephalopods, pp. 191-220. Rayong Coast. Fish. Res. Develop. Cent. Contrib. 18.

Thomas, R.F. and L. Opresko. - 1973. Observations on Octopus joubini: four laboratory reared generations. Nautilus, 87: 61-65.

Tranter, D.J. and O. Augustine. - 1973. Observations on the life history of the blue-ringed octopus Hapalochlaena maculosa. Mar. Biol., 18: 115-128.

Van Heukelem, W.F. - 1973. Growth and life-span of Octopus cyanea (Mollusca: Cephalopoda). J. Zool., 169: 299-315.

Van Heukelem, W.F. - 1977. Laboratory maintenance, breeding, rearing, and biomedical research potential of the Yucatan octopus (Octopus maya). Lab. Anim. Sci., 27: 852-859.

Van Heukelem, W.F. - 1983. Octopus cyanea. In: P.R. Boyle (ed.), Cephalopod Life Cycles Volume I. Species Accounts, pp. 267276. Academic Press.

Villanueva, R. - 1995. Experimental rearing and growth of planktonic Octopus vulgaris from hatching to settlement. Can. J. Fish. Aquat. Sci., 52: 2639-2650.

Villanueva, R. and M.D. Norman. - 2008. Biology of the planktonic stages of benthic Octopuses. Oceanogr. Mar. Biol. Annu. Rev., 46: 105-202.

Well, M.J. and J. Wells. - 1970. Observations on the feeding, growth rate and habits of newly settled Octopus cyanea. J. Zool., 161: 65-74.

Scient. ed.: V.D. Valavanis.

Received May 4, 2011. Accepted May 18, 2011.

Published onlie October 17, 2011. 